\title{
第32回 岡山大学医学部精神科・神経科
}

\section{臨床集談会 抄録}

昭和 48年 6 月 2 日岡山大学医学部図書館 3 階講義室

\author{
主催 大 月 三 郎 教授 \\ 〔昭和 49 年 8 月 8 日受稿〕
}

\section{1) Outpatient Management of Anorexia Nervosa}

\author{
岡山大学医・神・精 古元 順子 \\ 倉敷中央病院 久保 信介 \\ 岡山大学医・神・精 大月 三郎
}

2 年間に 6 例の anorexia nervosa の外来治璄を 試み中間報告を行う．方針として(1)身体の検查結果 を事実のまま示し栄養失調が放置されると死の危険 がある. (2)栄養失調に由来するamenorrhea を放置 すると卯果機能る廃絶する恐机がある（3)患者自身 が食へろ努力をしない限り栄養失調の回復は難しい。 併し努力して 6 胃腸機能の低下のため摂食が難しい こともあるので患者が希望すれば薬物を用いること が出来ろ．(4栄養失調が或程度回復すれば登校その 他の活動は行ってもよい.と告げ Periactinを主と する薬物投与と併せて患者およひ家族への Counse- ling を行った. その結果, 体重増加, 腹部症状の改 善と併行して家族の不安か減少し家族関係の改善お 上び学校での適応の改善がみられた．同時に患者は 肥満への不安を顕在化し，てれが家族の不安を增す という状況を起すが，(5)月経再来のため少く共年令 平均の体重まで回復する必要があるととを理解さ せ，終局的には身体症状改善に伴う適応の喜びを体 験させようとした．現在 6 例中転医した 1 例老除き 5 例が略病前の体重に復し 3 例が月経再来をみ, 全 例が家庭および学校での良好な適応を続けている。

\section{2) ヒステリーとうつ病の関連性について}

倉敷中央病院精神科 久保 信介

抑うつ状態を呈しているが, hysterical characterを有している一群がある。ヒステリーの特徽が， 転換症状よりもヒステリー独特のポーズ，対人関係 といったものに含まれるあるニュアンスにあるとす れは，本質的にヒステリーと考えられる。ここには
段階的な移行が考えられるが，それを理論つけるた めに, E. Fromm の性格類型の中の「受容的構え」 を引用して説明し, N. Reichの性格分折の中の ヒステリ一性格における抑うつ应的機制についての 理論を用いて述へた。 


\title{
3）教室における行動療法のあゆみ
}

$\begin{array}{rlll}\text { 岡山大学医・神・精 高橋 } & \text { 幸夫 } & \text { 大西 俊和 } & \text { 中島 豊爾 } \\ & \text { 安本 生子 } & \text { 和気 } & \text { 章 }\end{array}$

我々は 2 年前から行動療法を採用し,各種神経症， 心身症を扱ってきた．技法は主に，Wolpe 教授の逆 制止理論にもとず系統的脱感作，現実脱感作，断 行療法, 漸進的筋弛緩法を用いた。症例は27例で不 安神释症 6 , 痤性斜颈 4 , 本態性振戦症 5 , 書痤 3 吃音 3 , 眼䀫下垂 3 , 赤面恐怖症 1 , 過呼吸症候群 1 ，強迫神䅅症 1 例であった．そのうち治療したも の13例, 軽快例 6 , やや軽快ないし不変例は 8 例で あった，現時点での治楽率は70\%であり，再発は今 観察にまちたい，2年間の経験より次の点を反省し t.

(1)店例の行動分折（Behavior analysis）を上く行 い，それに応した技法を用いるべきである。

(2)一技法にてだわろ事なく，併せて他の技法も用い ろへきである.

（3治療場面汃ら現実場面への橋渡しには，森田的説 得断行訓練を用いる事により，それを速やかな らしめた.

\section{4 ) 重度精神発達遅滞と周期的気分变調を伴った Klippel-Feil 症候群の 1 例}

\author{
旭川児童院末光 茂 \\ 岡山労災病院神程科 末丸 紘三 黒田 邦彦 \\ 旭川療育園 守谷 節夫
}

18才男子, 臨床上短預, 後頭部の髮の生え際の低 下および頭頚部運動制限.レ線上第 $2 ， 3$ 曒椎の療 合をみるも数的欠損や spina bifida をみず, Feil の第 2 型． 右上下肢の趾反射の軽度六進をみるも， 病的反射なく，知覚系に異常なし，筋電図で lower neuron damage の所見なし.脳波で左 temporal に つよいsporadic な $3 \mathrm{cps}$ spike and wave み るも，臨床上の発作を一度もみとめず．体知覚性誘
発電位，髄夜に異常なく，通過障害と思われる所見 なし１5，6才より下肢の運動障害が湿著となった が，検查所見から脊賄性でなく，脳性之考えた．鈴 木ビネーにてIQ17.17才の夏より躁うつ状態に似た 精神症状が，ほほ 1 ヶ月の周期で出現し，Imipramine, Diazepam 投与に反応, 断薬で再然し, 再投 与で症状消失した．それらの経過を報告し，本症の 合併する精神神経症状について文献的考察を加えた。

\section{5 ) Gamma-hydroxybutyrate による臨床脳波賦活法について}

\author{
皘善病院 平田潤一郎 \\ 高橋＼cjkstart幸夫 \\ 公立上下湯ヶ丘病院 細川 清品川 昌二 \\ 岡山大学医・神・精 平田 邦樹
}

\begin{abstract}
Gamma Hydroxybutyrate (GHB) を体重kg あた り 20 25mg を静注後, 20分以上の記録で次の結果を 得た。健常対照成人100名で $12 \pm 6$ 分後に85名か入眠, 内49例は入眠前期に一過性の $\theta$ 波群発を認めた。全 例之もその後，ほほ自然睡眠類似の経過をたどった。

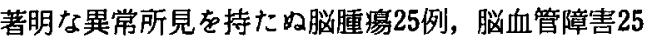

例，その他の器質性脳障害29例において，賦活前正 常脎波であって陚活により局在性徐波などの明確な 異常所見を示したもの14例（17.7\%），不明確であ いまいな所見が明確な所見となったもの22例（27.8 \%)という結果を得た，局在部位別にみると，半球 性障害 22 例中 15 例 $(68.2 \%)$ ，深在性 24 例中 10 例 
$(41.7 \%)$ ，天幕下性，4 例中 2 例（50\%）飞著明 な効果を認めた，てんかん108例では，棘波成分の開 発賦活21例（19.4\%），増強賦活17例（15.7\%）で
あり，特に精神運動発作で効果が高かった．副作用 は一過性の軽度の供急, 頭重, 嘔気, などがあった が，64.6\%では何らの副作用はなかった。

\section{6）退院後治療を続ける分裂病患者の再入院率について}

$\begin{array}{rlll}\text { 県立岡山病院 生盛 敦子 } & \text { 富井 } & \text { 通雄 } & \text { 田辺 研二 } \\ \text { 吉岡晋一郎 } & \text { 岡部 健雄 } & \end{array}$

昭和 42 年 1 月上り昭和 45 年 12 月までに，県立病院 退院した分裂病患者で, 昭和48年 1 月まで継続し て治療を受けている315例を対象として，それぞれの 退院年度別の再入院率支調査した。

各年度に上り若干の差異はあるが，3 年ないし 4 年後には，いずれも70\%近くが再入院を経験してお ク，その間常に社会生活を維持したものは $30 \%$ 余に
すぎない.

ただし，松沢病院の報告によると，非通院群に比 し, 通院群の方が再入院率は低くなっており, 昭和 45年度の我々の資料に扔いても，再入院率は，乙れ 上り更に低くなっているので，今後治療の技法を工 夫することにより，再入院率をさらに低くすること は不可能ではない。

\section{7 ）小児自閉症のトリプトファン代謝, 第 1 報, 血清セロトニン值について}

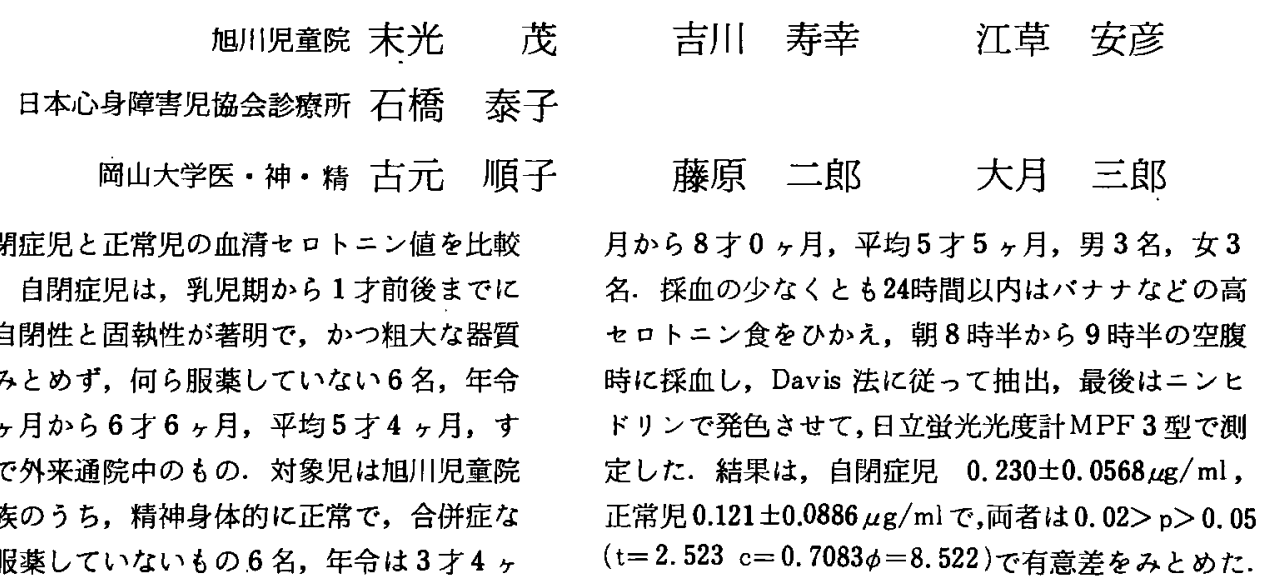

\section{8 ）重症リチウム中毒の一治験例}

\section{河田病院 松田＼cjkstart清止藤 恵子 岡山大学医・神・精 池田 久男}

症例：44才，男子. 26才で発症し頻回の再燃を繰 り返している躁榡病患者である，炭酸りチウム一日 $600 \mathrm{mg}$ 経口投与治療開始後 39 日目より, 特に誘因な く発熱，全身倦虫，食欲不振を訴え 3 日後には無欲 状で応答遲延, 言語障害, 手指振戦, 失見当識が出 現し，意識水準の低下に気付かれた．極期にも意識
障害は昏棰に至らず一見 akinetic mutism を思 わせる独特の状態で，あろ程度は外界刺激に反応す ろが自発的言語は全くなく眼球は固定し無表情であ ろ. 神経学的には眼輪筋, 口輪筋, 四肢筋の線稚束

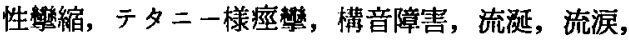
嶼下困難, 筋吒打時にみられる粗大振戦, 縮の漸 
増現象か特徽的である.中毒症状はリウチム中止後 も数日にわたり増悪し約 2 週間持続した. この間の 症状や脳波所見の推移を血清・艏液リチウム濃度の
変化と関連し検討すると共に，中毒時の管理，治療 を紹介する。

\section{9 ) 向精神薬療法中に急性脳炎類似症状を呈した一例}

公立上下湯ヶ丘病院 久鄉 敏明品川昌二 細川清

症例 60 才女性 精神分裂病

家庭歴 既往歴 特記事項なし

幻党, 妄想, 情意鈍麻等を主症状としクロルプロ

マジンを中心とする向精神薬の比較的多量投与療法

中に意識障害をもって発症, 種々の神経学的症状を
認め 4 日間の昏睡ないし亜昏睡状態を経過したがス プールロスに回復せしめ得た.

我々は本例を臨床的に薬物に上る中毒性脳炎と考 え, 病理学的に脳浮腫の存在を推測した。また肝機 能障害との関連についても若干の考察を加えた。 


\title{
第33回 岡山大学医学部精神科・神経科
}

\section{臨床集談会 抄録}

昭和 48年12月 8 日岡山大学医学部図書館 3 階講義室

主催 大 月 三 郎 教授

〔昭和 49 年 8 月 8 日受稿〕

\section{1）脳腫瘍の一剖検例}

\author{
慈圭病院 斉藤 章 三井尚 \\ 岡山大学医・神・精 馬場 修
}

4 ヶ月来, 全身僚急感と頭痛を主訴として, 内科 で治療をうけていた47才の女性が，不眠，多弁多動 の状態になり，精神病院に転院してきた．初診時， 軽度の意識障害, 歩行障害, 咀膜刺激症状, 脳神経 症状か認められた，脳脊蹃液検查に上り，铕膜炎が 疑われたが, 剖検の結果, 脳幹,小脳上面の軟脳膜,
右側頭葉内側下面，脳室上衣の広範囲にわたり，腫 㷎組織がみられ, meningeal sarcomaと判明した。 脳以外の缄器からの転移の有無は未定である. 以上 のビマン性の脳病変と臨床症状との関連を中心に考 察した.

\section{2 ）急性脳症と思われた一例一 剖検例 一}

\section{姫路中央病院 東博文東漸 岡山大学医・神・精岡本繁 石野 博志}

50才男子. 微熱, 頭痛, 食欲不振等の感冒様症状 にひき続き, 頭痛, 嘔吐, ついで不眠, 興坴状態と なり来院. 入院後発熱, 痙戀, 呼吸停止きたし, 全 経過的 3 週間, 急性期約 12 日間で死亡した，検査で は胸部レ線上著変ない, 顝液は圧, 総蛋白量, 細胞 数共に著明堌加. 糖は減少. フィブリン析出なし. トリプトファン反応陽性. 結核性随膜炎が疑われた
が抗結核剤に過敏性があり，充分用い得なかった。 剖検では脳はいわゆる respirator brain で外形で は血管の充血著しく，軟膜の肥厚混濁，一部にクモ 膜下出血もある. 組織標本ではクモ膜の結合織化, 軟膜血管の外膜炎，トロンボーゼ，巨大細胞，典型 的な肉芽腫などがあり，チールニールセン染色で結 核菌を諗めた。

\section{3) 電整，インシュリン，ロボトミー各療法後の長期予後について \\ 笠岡病院 西岡 博輔 \\ 岡山大学医・神・精 大下 俊則

$\begin{array}{lll}\text { 安田 達司…… 小寺 } & \text { 政子 } \\ \text { 福井 秀明 } & \text { 大西 俊和 }\end{array}$

12年以上の病歴を持ち, 既往の治療のはっきりし ている, 入院中の精神分裂病患者 100 名について，そ の予後調查をした.(1)分裂病の基本症状はどの治療
法によっても改善されていない（2遗伝負因の有無 は予後に関係がない（3記銘力障害は電撃群 (32名) 電撃+Insulin群 (48名), 対照群（17名）のいずれ 
においても認められない.電撃回数との関係ちない. (4)自発座慗は電撃+Insulin群においてのみ4例見ら れた。.これらも最近 5〜15年間発作がない.(5)脳波 異常の出現率は各群の間に差がなかったが，どの群 も徐波化傾向が見られ，発作波も異常脳波の $30 \%$ に 出現している，異常波の好発部位は前頭葉，側頭葉
であろ. (6)PEG（10例）は，対照群を含めて全例に 脳室系の拡大, 非効称, 皮質の異常のいずれかの病 的異常を示した. (7)今回のいずれのデータにおいて も, 電擊群と電撃+Insulin群の間に影著な差はなか ったが, lobotomy 群（3 名）が一番悪い成績であっ た.

\title{
$4 ）$ 入院患者に対する投薬方法の検討（1 日 2 回投薬について）
}

\author{
福山仁風病院 枝松一安河野 沢與 \\ 川崎医科大学・精・渡辺昌祐
}

精神科の臨床では，向精神薬の投薬は，1日量を， 3 回に等量に分割する方法が行われているが，その 理論的根拠は疑問である.

最近，われわれは，2つの病棟，すなわち，治療 病棟之老人病棟の男子患者に, 1 日 2 回投薬を行っ て経過を観察したので報告する。

1 日 2 回投薬によって，催眠薬は不要となり，精
神症状の要化したものはなく，向精神薬を减量する ことができた，患者は，㡺の間の鎮静が軟らげられ ろため,病室での行動評価が改善された. 看護者は, 投薬に要する時間が减り,夜間の問題が少なくなり, 病室が明るくなったため，昼の間の勤務も楽になっ た.

\section{5 ）うつ病の精神療法 一その問題点と可能性についてー}

うつ病の精神療法は, その回復期に特に重要であ ろ. 回復期は病者は症状が消失し, 社会復帰を用意 し始めており，精神療法的かかわりあいは，浮き足 立っているが,パーソナリティに衝きかけるてとを 目的とする場合，ての時期は治療導入期とも云える が，病者の社会復㷌により中断することになる。乙 こにうつ病の精神療法の困難な状況がある.しかし， 回復期には病者に，彼の性格特性，対人関係などに
倉敷中央病院精神科 久保 信介

ついての問題意識，自覚を持たせる必要がある，そ れはうつ病が再発しやすく，覆延するととが稀でな いととを考えると特に重要である．治療者は病者と の最初の出合いにおいて，上の理由のために，長期 の治療体勢が必要であり，段陵的なかかわり合いを 予測することで，より深く病者のパーソナリティに 働きかけうろ可能性があると考える。

\section{6 ）小児の発達段階別にみる起り易い心的外傷と挫折症状一小児外来報告一}

\author{
岡山大学温研 古元 順子 \\ 岡山大学医・神・精大月 三郎 \\ 高見病院 杉山 信作 徳山翠
}

過去3年間に岡大小児精神外来を受㟝した157名中 心理的外傷に関連して発症したと思われる，122名に ついて発症時期を発達年令別にみると $0 \sim 1 才: 24$ 名, 1 3才：25名，3－6才：1名，6１1才： 23名, 11〜18才：49名であり $3 \sim 6$ 才で発症するも
のは極めて少い, psychotic disorderは0３才 群と11〜18才群にみられ前者では autistic manifestation を，後者では schizophreni-form をとるて とが示された．種々の障害における発症の precipitating factorまたはbasic traumaをみると, 0 一 
1才群では母または子側のいずれかに由来する心理・ 感覚刺激の deprivation が全例にうかがわれ 1 才群では母または子側の種々の理由による separation problemが全例にうかがわれた. 6〜11才群お よび11〜18才群では transient reactive disorder を除いて略全例に，基本的にはそれそれれの発達段階
以前に達成されろべき依存からの自立が充分でなく， 後者では更に次の段階で達成されているべき性的同 一化が充分に行なわれていないととがうかがわれて いろ. また耐群の種々障害の precipitating factor についても言及した。

\section{7）絶食㫫法について}

$$
\text { 広島市民病院神経科二宮 㴟明 }
$$

2 例に絶食療法を行った。. 絶食期間は10日間で, その間, 水あるいは茶を飲むこと以外には, 面会, 読書など一切禁止し, 日記をつけるととのみを許可 した.

症例 1，31才の男. 慢性軽うつ病. 昭和 46 年 6 月 頃より抑うつ気分, 心気念虑, 倦意感, 意欲減退, 頭痛, 嘔気を生じ, 心気うつ病として諸種治療を行 ったが全く変化をみず, 慢性うつ病の感を呈して来 た. 48年10月 3 日より絶食療法開始，5 日目頃より やゃ明朗活発になり, 復食期の終了と同時に退院. 現在, 中心症状である心気念慮は残しているが, 社
森田 博方 好永 順二

会生活は出来ている.

症例 $2 ， 23$ 才の女. ヒステリ一。昭和47年 6 月， 頭痛, 嘔吐. 次いで倦急感, 食思不振, 不眠, 失立 発作, 更に48年 8 月より 1 日十数回の嘔吐をみるよ うになった，同11月 5 日より絶食療法を開始，嘔吐 頭痛など軽堿はしたが, 社会生活可能な域には至ら なかった。

上記 2 例はいずれも $1 \sim 2$ 年間に亘って, 諸種治 療に抵抗して改善をみなかった例で，おほれる者は ワラをもつかむ感じで，動機づけは容易であった。

\section{8 ）退院後患者の集団的症状管理についての一つのこころみ}

\section{帆秋精神病院 帆秋 孝幸}

近年, 精神病に対する向精神薬の開発や, 治療技 術の向上に依って, 社会復帰可能な患者が増加して きた.しかし，寛解退院した患者6暫らくすると症 状か再発し，再入院してくろケースがかなりある。 てれは，ての病気がもっている特殊性にもよるが， 更に，退院後の治療的環境や闘病習慣が失われるこ とに依ると思われる. そこで，われわれは，退院後 の患者の再発, 再入院を防止するためには, 従来の 外来通院だけでは不充分と考え, 外来で患者の闘病 会をつくり指導することにした.

会は月に1回, 日曜日に開催し, 外来患者を中心 にし，希望に依って在院中の退院予定患者若干名を

\section{帆秋 䅖誉 \\ 土井享}

加え, それに補佐機構として, 担当医師, 看護婦が 加わって開く. 先ず, 各自より 1 ヶ月間の闘病努力 の報告をし，それを皆で検討し，ついで担当医師が 闘病指導して散会する.指導目標は, 闘病の孤独性 をなくし，闘病を自己の問題として真正面からとり 組んでゆく姿勢を持だる，再発のさいは病勢が進 行して病識を失い, 闘病拒否か現われる前に早期症 状を自覚させ，それが適切な受療につながるように することなどである，てうして，会の発足した昭和 44年 8 月より現在まで 1 回の流回もなく続いており, 会員の再入院も減り, 各自の闘病姿勢も確立されて きている。

\section{9）慢性酒精中毒と頭部外稘}

\section{土佐病院 須藤浩一郎鈴木 常夫}


であろ．昨年12月より本年11月の間に土佐病院に入 院したアルコール中毒患者 21 名中13名（約62\%）か～ 入院によろ急激な断酒によりせん妄を来した。 との 椂にせん妄の発現頻度が高いため, 入院時や入院後 意識障害が出て来るとアルコール禁断によるものと の先入観を持ち易い. 最近これらの患者の中で，慢
性又は亜急性硬膜下血腫による意識障害であったが, 時間的に禁断後又は禁断によるせん妄にひきつつき 出現したとと，頭部外傷が軽度であったとと，及び 脳圧六進症状や局所神䅅症状が認められなかったて と等のために，アルコール禁断症状の意識障害と鑑 別が困難であった 2 例を経験したので報告した。

\title{
10) Contingent Negative Variation(CNV)の頭皮上分布及び学習効果につい
} $\tau$

\author{
岡山労災病院神経科 末丸 紘三 黒田 邦彦
}

昨年の第31回本集談会において, CNVが attention, motivation, expectancy などの心理現象を表 現するものであるととを報告した，今回は，CNVの 頭皮上分布及び学習条件つけについて検討した. (対 象は全て健康成人) 結果：1) CNVの頭皮上分布は, 全脳対称性, 頭頂前頭部優位である，2) 潜在学習 を受けている者（技術員）では $S_{1}-S_{2}-R$ 標準手
秸きをしなくても $\mathrm{S}_{1}$ のみで CNVは出現してくる， 3）他の一般被験者では $S_{1}-S_{2}-R の 一$ 連の訓練後, $\mathrm{S}_{1}$ のみでCNVは条件つけられる４）Ｓ，を消去又は $\mathrm{S}_{1}$ に擬音を加え $\mathrm{S}_{1}$ の混乱を起すと CNVは消失した り低下する. 即ち，CNVの出現には $S_{1} か ゙$ 必ず必要で ある．5) 再条件つけをすることにより CNVは更に 强化学習される.

\section{1）過去 2 年間に経験した多発性ノイロパチーについて}

\section{高知県立病院神経科三宮 崇典横溝潔石垣一彦}

過去 2 年間に多発性ノイロパチーを53例経験した ので統計的にまとめて報告した.

発病年合は14才から72才にわたり，10才台と40才 台にピークがあり 2 峰性を示した。性別では男35例 女18例であった．原因別分類では感染15例（うち Guillain-Barre 4 例）代謝異常 8 例（糖尿病性 4 例, アルコール性 3 例, 産㜊 1 例）中毒13例（抗結核剤 6 例, ボンド 3 例, シンナー 2 例など) 悪性腫場 2 例, 原因不明15例であった，症候学的には運動麻㾝
のあるもの（混合型を含む）32例，知覚障害のみの もの21例とほぼ $3 ： 2$ の割合であった．障害の程度 別では mild 9 例, moderate 34例, severe 10例で, severeはエサンブトール,ボンドなど中毒性のもの に多く見られた．経過を追跡し得た37例の予後は完

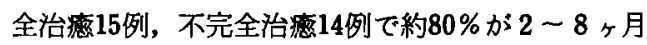
で軽快し，覀化したのは 2 例のみであった．筋電図 にて42例中35例に神経原性パターンが見られ，脳脊 髄液にて24例中 7 例に蛋白細胞解離が見られた。

\section{2）急性脳神経炎によると思われる両側動眼神経麻㾝の1治匰例}

\section{三宮 崇典横溝 潔}

症例は75才男性, 既往歴: 昭和 28 年左顔面神経麻 疸, 昭和46年高血圧, 心疾患あり。現病歴：S 48年 5 月 15 日 $39^{\circ} \mathrm{C}$ の発熱し, 解熱後 1 週間して複視, 左 眼䀫下垂,ついで右眼䀫下垂を来し 6 月 4 日当科入 院. 入院時神経学的に左瞳孔散大, 左対光, 輻奏反 射ともに消失, 右瞳孔正常, 両側完全眼䀫下垂あり。 眼球運動は両側とも内方,上下方へ完全な障害あり.
左側額のしわ寄せ弱く口角右へ引かれる．四肢運動 知覚障害, 失調ともになし，以上動眼神経支配域の 両外眼筋麻瘦, 左内眼筋麻㾝, 左末梢性顔面神経麻斬 が見られた，検査では白血球増多，血沈元進，リコ 一ルにて細胞数增多あり. EEGにて左半球に間歇性 異常あるも脸血管写に異常なし. 6 月11日よりプレ ドニゾン，ビタメジン等投与し右外眼筋, 左外眼 


\section{シンポジウム 分裂病患者の社会復帰}

1) 小グループの共同住居による分裂病患者の社会復帰の試み

福山仁風荘病院 枝松一安

2）嶘製工場に於ける分裂病退院患者の動向

湯ヶ丘病院 久郷 敏明

細川 清 品川 昌二

3）社会復帰㞠法の理論

松江精神病院 渡辺宏

4 ) 中間施設についてーその現況と考察 -

積善病院 平田潤一郎

5 ) 私どもの考える病院医療と社会復帰

県立岡山病院 富井通雄

6) 地域性精神活動と社会復帰

精神衛生センター山本 昌知 